\title{
The dynamics of healthscaping: mapping communal hygiene in Bologna, 1287-1383
}

\author{
Taylor Zaneri $^{1 \star}$ (D) and G. Geltner ${ }^{2 \dagger}$ \\ ${ }^{1}$ Department of History, University of Amsterdam, Kloveniersburgwal 48, Amsterdam, The Netherlands \\ ${ }^{2}$ Department of History, University of Amsterdam, Kloveniersburgwal 48, Amsterdam, The Netherlands \\ ${ }^{*}$ Corresponding authors. Email: t.l.zaneri@uva.nl and g.geltner@uva.nl
}

\begin{abstract}
This article traces how urban communities operating with a humoral or Galenic medical paradigm understood and confronted the health challenges facing them, using the extraordinarily well-documented case of Bologna, Italy. Working within a GIS environment, the authors spatially analyse over 3,500 events recorded by the Ufficio del fango concerning violations of the city's health-related ordinances, augmented by other demographic and material data. As such, the study not only adds specificity to recent attempts to enrich the field of pre-modern public health, but also demonstrates that the Bolognese administration had a sophisticated and evolving understanding of communal health risks, and exposes several discrepancies between policy and practice.
\end{abstract}

\section{Introduction}

The integration of archival and archaeological data in a GIS environment is a boon to the field of public health history, and urban history more broadly. ${ }^{1}$ In particular, it pushes scholarly debates beyond questions of whether earlier cities devised

\footnotetext{
${ }^{\dagger}$ An earlier version of this article was discussed with great benefit at the Rachel Carson Center's 'The nature of health, the health of nature' conference, hosted by the Renmin University in Beijing. For their insights and comments, the authors would like to thank the latter's organizers and participants, the journal's anonymous reviewers and the 'Healthscaping urban Europe' (ERC Consolidator Grant no. 724114) team: Claire Weeda, Janna Coomans and Lola Digard. The Archivio di Stato di Bologna continues to be a uniquely pleasant and productive place to work, and we would like to acknowledge our debt to the local staff and scholars, especially Massimo Giansante, Rosa Smurra, Rosella Rinaldi and Daniele Bortoluzzi. These efforts will culminate in June 2021 in a launch of medieval Bologna's online health map.

${ }^{1}$ For the use of historical data in GIS, see A.K. Knowles and A. Hillier (eds.), Placing History: How Maps, Spatial Data, and GIS Are Changing Historical Scholarship (Redlands, CA, 2008); D. DeBats and I. Gregory, 'Introduction to historical GIS and the study of urban history', Social Science History, 35 (2011), 455-63; I. Gregory and A. Geddes (eds.), Toward Spatial Humanities: Historical GIS and Spatial History (Bloomington, 2014); I. Gregory and P. Ell, Historical GIS. Technologies, Methodologies and Scholarship (New York, 2007). Key archaeological texts include J. Conolly and M. Lake, Geographical Information Systems in Archaeology (Cambridge, 2006); A. Scianna and B. Villa, 'GIS applications in archaeology', Archeologia e Calcolatori, 22 (2011), 337-63.

(C) The Author(s), 2020. Published by Cambridge University Press. This is an Open Access article, distributed under the terms of the Creative Commons Attribution licence (http://creativecommons.org/licenses/by/4.0/), which permits unrestricted re-use, distribution, and reproduction in any medium, provided the original work is properly cited.
} 
preventative programmes and towards how such programmes shaped and in turn were shaped: by a range of administrators, by cities' physical, social, political and biological environments and by contemporary interpretations of risk and health by diverse residents. Moreover, the (sometimes unexpected) correlations and divergencies exposed by working in a digital platform enriches pre-modern urban historians' toolkit in exploring a range of questions about cities' morphology, metabolism, industry, social life and more. Last but not least, data safely mapped is also data responsibly stored for augmentation, reuse and appropriation by further scholars and projects, including in comparative synchronic and diachronic contexts. Late thirteenth- and fourteenth-century Bologna is a case in point, thanks to typical yet exceptionally well-preserved sources.

Like numerous European cities in and beyond its highly urbanized region, Bologna too devised and enforced preventative health measures designed to impact all residents. ${ }^{2}$ It did so, moreover, in dialogue with a prevalent medical and natural-scientific system known as Galenism, whose interests in the inter-related aspects of physical and social health were deep and manifest. The Galenic prism privileged here is emphatically not an exclusive one. Concepts of health and nature do not always and everywhere descend from an intellectual elite downwards (let alone along a single path), and are more likely negotiated between individuals and communities, and between governments and citizens on an ongoing basis. What is more, ideas and practices co-exist among competing theories and objectives, and have to reckon with physical urban infrastructure as well as the practical limitations of households, neighbourhood officials and urban government. Nonetheless, preventative action and Galenism constitute a central nexus for understanding public health across vast regions for more than two millennia, and whose operation Bolognese sources and their analysis shore up.

The present article begins by briefly explaining the latter paradigm, before moving to examine evidence for municipal policy concerning the promotion of healthy environments, in particular as it emerges from studying the records of Bologna's roads officials, also known as the fango or dirt masters. Their richly documented activities, augmented by further data, provide the basis for a geospatial analysis, which focuses on two critical aspects of urban health as both predictors and subjects of preventative interventions, namely waste disposal and hazardous commercial activity. The level of spatial accuracy, along with the quantity and richness of the data, is extraordinary for the late thirteenth and fourteenth centuries and permits sophisticated and detailed analyses for Bologna. More scarce but identical records from additional cities (not analysed in this article) strongly suggest that this sophistication was typical at least throughout the Italian peninsula's centre and north.

The use of spatial analysis in the domain of public health is hardly new; reflecting linkages between place and health goes back millennia. Some scholars have termed this 'medical geography' or 'health geography', that is, the application of a spatial perspective to human and environmental health. One of the most notable

\footnotetext{
${ }^{2}$ For England, see C. Rawcliffe, Urban Bodies: Communal Health in Late Medieval English Towns and Cities (London, 2013); for Italy, see G. Geltner, Roads to Health: Infrastructure and Urban Wellbeing in Later Medieval Italy (Philadelphia, 2019); for the Low Countries, see J. Coomans, Community, Urban Health and the Environment in the Late Medieval Low Countries (Cambridge, forthcoming).
} 
examples of this is John Snow's cholera map drawn during the 1854 epidemic in London. ${ }^{3}$ With the development of GIS, researchers in the 1980s and 1990s undertook public health studies to map the spread of infectious diseases, as well as to identify environmental hazards or other spatially dependent risks. ${ }^{4}$ While the use of GIS is common in modern epidemiological and public health studies, its employment in historical and especially pre-modern health studies is relatively recent. Still, there are several successful examples which point to the potential of GIS analyses in this field; these include the DECIMA project for early modern Florence, ${ }^{5}$ along with several studies which have mapped the transmission of Yersinia pestis to and within Europe. ${ }^{6}$ Our study, while building on earlier methodologies, focuses on another important aspect of health: the cleanliness and hygiene of Bologna in the later thirteenth and fourteenth centuries, as it related to the disposal and management of waste as recorded by the Ufficio del fango. In doing so, it broadens the scope of pre-modern health studies in GIS.

Many datapoints in this study were recorded by urban officials, who noted the parish church (and more rarely the market or street) in which the offence took place. For locations outside the city walls, generally only the town or rural parish in which the charge was noted. However, most of the allegations the fango officials noted were inside the city itself. We have included all offences in the table in the Appendix, but for this study we have only mapped those events which took place within an urban parish. These were in turn mapped on the basis of the parish, except in cases in which the market or street was specified. There were nearly a hundred parishes in the period under examination, and most church structures still exist today and are readily identifiable. These locations were crossed with population figures from the year 1296, also collected by parish, recording every head of household that year. The combination allows for a detailed study, not only of what city officials claimed they detected, but also how their activities and routes were

\footnotetext{
${ }^{3}$ G. Musa et al., 'Use of GIS mapping as a public health tool - from cholera to cancer', Health Services Insights, 6 (2013), 111-16; M. Meade and M. Emch, Medical Geography (New York, 2010), 73-6; J. Mayer and M. Meade, 'A reformed medical geography reconsidered', Professional Geographer, 46 (1994), 103-6; R. Kearns, 'Place and health: towards a reformed medical geography', Professional Geographer, 45 (1993), 139-47. See also R. Kearns and D. Collins, 'Health geography', in T. Brown, S. McLafferty and G. Moon (eds.), A Companion to Health and Medical Geography (Chichester, 2010), 15-32. For an analysis of Snow's cholera map, see T. Koch, Disease Maps: Epidemics on the Ground (Bristol, 2011). And see T. Koch, Cartographies of Disease (Redlands, CA, 2005).

${ }^{4}$ See P. Kanaroglou, E. Delmelle and A. Paez (eds.), Spatial Analysis in Health Geography (London, 2018). For a methodological overview, see A. Gatrell and S. Elliott, Geographies of Health: An Introduction (Chichester, 2015).

${ }^{5} \mathrm{~N}$. Terpstra and C. Rose (eds.), Mapping Space, Sense, and Movement in Florence: Historical GIS and the Early Modern City (London, 2016), in particular in this volume, J. Henderson and C. Rose, 'Plague and the city: methodological considerations in mapping disease in early modern Florence', 125-46, and N. Eckstein, 'Mapping fear: plague and perception in Florence and Tuscany', 169-86. See also J. Henderson, Florence under Siege: Surviving Plague in an Early Modern City (New Haven, 2019).

${ }^{6}$ For plague studies using GIS, see M. Welford and B. Bossak, 'Revisiting the medieval Black Death of 1347-1351: spatiotemporal dynamics suggestive of an alternate causation', Geography Compass, 4 (2010), 561-75; B. Schmida et al., 'Climate-driven introduction of the Black Death and successive plague reintroductions into Europe', PNAS, 112 (2015), 3020-5; R. Yue, H. Lee and C. Wu, 'Trade routes and plague transmission in pre-industrial Europe', Scientific Reports, 7 (2017), 1-10.
} 
impacted by the distribution and concentration of people and industries across the city.

Subsequent sections consider periodization, professional occupation and most importantly location, in order to trace continuity and change in preventative programmes, underscoring the opportunities offered as well as the limits imposed by using a Galenic prism. The conclusion situates the results of the Bolognese casestudy in and beyond its region to underscore first, the preponderance of similar prophylactic programmes in an era better but wrongly known for its hygienic apathy; and secondly, the possibilities of fostering a more informed dialogue with scholars exploring other urban environments and reconstructing an emic understanding and experience in earlier periods.

\section{Galenism}

Since Antiquity, and for more than two thousand years, physicians, policy-makers and urban officials laboured under the medical paradigm known today as Galenism or humoralism, a system introduced in Hippocratic writings such as Airs, Waters, Places and Epidemics in the fifth century BCE, and further developed by Galen (129 - c. 200/219 CE) and his students in later centuries. At its core, humoral medicine sought to define and preserve a certain balance (symmetria) between an individual's four bodily humors: blood, yellow bile, black bile and phlegm. Yet Galenism foresaw no ideal, or for that matter, perennial balance even within an individual body's humors, since bodies too were enmeshed within a highly dynamic and complex natural system, itself constantly striving for balance. Thus, while Galenic authors and practitioners gave much thought to one's origins, including parentage and place and date of birth, they were no less reliant for insights into an individual's constitution (also known as complexion) on one's social, cultural and economic circumstances, and the climatic attributes of one's residence or itinerary. Personal and communal health, therefore, were not merely a stable balance of four humors, but rather a vibrant interplay among numerous tendencies and qualities, all in a state of constant flux. As such, the system's complexity foreshadows recent environmentalists' and ecologists' conceptualization of the balance of nature. ${ }^{7}$

Commentators on the Galenic corpus, probably in fourth-century Alexandria, began specifying that personal and collective health could be shaped by several external factors that came to be known as the 'six non-naturals'. Five of these were quite organic and behavioural, namely sleep and wakefulness, exercise and rest, food and drink, secretion and excretion, and mental affections, while the main quality of a sixth - air - was more decidedly environmental. ${ }^{8}$ The articulation of these six aspects underscored yet again how much the goal of Galenic health consisted in finding equilibrium, one might say even tentative peace, among

\footnotetext{
${ }^{7}$ S.L. Pimm, The Balance of Nature? Ecological Issues in the Conservation of Species and Communities (Chicago and London, 1991).

${ }^{8}$ L.J. Rather, 'The six things non-natural: a note on the origins and fate of a doctrine and a phrase', Clio Medica, 3 (1968), 337-47; L. García-Ballester, 'On the origins of the six non-natural things in Galen', in J. Kollesch and D. Nickel (eds.), Galen und das hellenistische Erbe: Verhandlungen des IV. Internationalen Galen-Symposiums veranstaltet vom Institut für Geschichte der Medizin am Bereich Medizin (Charité) der Humboldt-Universität zu Berlin 18.-20. September 1989 (Stuttgart, 1993), 105-15.
} 
often competing needs. Conversely, when a person or society failed to steer itself towards such balance, disease would ensue. For disease was shortage, excess or an imbalance produced either by individual misbehaviour or inadvertent exposure to harmful elements caused by ignorance, sabotage or neglect.

Galenic medicine, in other words, espoused prevention through correct behaviour and a programme of environmental upkeep designed to reduce harm, including when it came to spreading disease. Before germ theory became prevalent - a rather recent development - it is often forgotten that societies working within a humoral paradigm recognized two, partly overlapping vectors of disease transmission. The first was miasma, air corrupted by decomposing matter, which in turn assaulted those who were exposed to it either through skin contact or by inhaling it through the nose or mouth. Reducing miasma or else avoiding it altogether was therefore a key plank in any environmental protection programme. The second vector was ocular intromission, that is the implantation of disease through one's observing eyes as they took in corrupted matter such as blood, dung, stagnant water or rotting carcasses. Reducing these matters' presence in the urban environment or else promoting ways to avoid them, for instance by industrial zoning, regulating burials and instructing butchers on how to dispose of their waste, was a common technique used by urban regimes explicitly pro maiori sanitate hominum, for people's greater health. ${ }^{9}$

Already prevalent in the Greek and Roman worlds, the humoral approach to the human body and its environment lived on in Byzantine and Arabic medicine (which also took it across Eurasia and the Indian Ocean), and was picked up steadily since the eleventh century in western Europe, with southern Italy and Spain often acting as bridgeheads of textual and practical transmission. Armies, monasteries, trade convoys, pilgrims, the papal court and of course cities and their new universities were all hubs of deliberation and experimentation with new and revived forms of prophylactic measures. And it was here, under Latin Christian hegemony, that both miasma and intromission were also conceptualized as the result of moral and not merely physical corruption, leading to devising preventative programmes that made no essential distinction between communal piety and physical well-being. ${ }^{10}$ To be sure, pursuing preventative behaviours to promote health was challenging enough on a personal and domestic level; maintaining such standards city-wide required significant resources and a broad co-operation among different stakeholders. If people were to stay healthy, there was a broad consensus that everyone had to contribute to cities' healthscaping, that is to create a place where health could bloom.

\footnotetext{
${ }^{9}$ R. Greci, 'Il controllo della città: l'ufficio dei fanghi e strade a Bologna nel XIII secolo', Storia della città, 47 (1988), 119-24; Geltner, Roads to Health, 34-67. See also R. Greci, 'Il problema dello smaltimento dei rifiuti nei centri urbani dell'Italia medievale', in Città e servizi sociali nell'Italia dei secoli 12.-15 (Pistoia, 1990), 439-64.

${ }^{10} \mathrm{P}$. Horden, 'Ritual and public health in the early medieval city', in S. Sheard and H. Power (eds.), Body and City: Histories of Urban Public Health (Aldershot, 2000), 17-40; A. Agresta, 'From purification to protection: plague response in late medieval Valencia', Speculum, 95 (2020), 371-95.
} 


\section{Urban healthscaping, viarii and the Bolognese fango officials}

As urban (and princely, and papal) regimes across western Europe attempted to centralize and buttress claims to legitimacy, stressing their role as being responsible for their subjects' health became a rhetorical and practical commonplace, informing policies designed to define and protect the public good. Street cleaning, labour safety, artisanal zoning, waste disposal, animal rearing, produce quality at the market and in taverns, curfew, the location of alms houses and leprosaria and the hiring of communal physicians: all were biopolitical measures consciously presented and often understood as reducing harm and promoting health at the population level. ${ }^{11}$ Less visible in urban historiography, perhaps, but no less influential in rolling out these policies across Italy were infrastructure specialists: public works or roads officials (viarii), known uniquely in Bologna as the fango or dirt masters. Their key task was to build and maintain public amenities, including canals, roads, bridges, walls, fountains and markets. ${ }^{12}$ Yet in doing so, they often became a regime's eyes, ears and noses on the ground, detecting and addressing violations and neglect perceived - also from a Galenic perspective - as threatening to neighbours and visitors by causing miasma and intromission. ${ }^{13}$ At a very pedestrian and thus influential level, therefore, roads officials served as healthscapers, defenders of the urban environment in myriad sites in each city. What follows is the analysis of one such outfit, operating in Bologna at least since the mid-thirteenth century. It is based on the outfit's well-preserved records, alongside information on the city's topography and its evolving demography and morphology, which combine to demonstrate how residents defined and promoted urban health and the extent to which a Galenic thought informed these practices.

In the fango office, Bolognese magistrates created a tool for identifying perceived physical and moral health hazards, often relying on Galenic terms, which provided a legal means to report and deter risky behaviours. The office itself comprised a small group of mid-ranking officials whose job involved building and inspecting the city's roads, wells, buildings, markets and other (putatively) public infrastructures, documenting violations and hazards involving improperly disposed waste, blocked doorways and egresses, unsealed roads, unsafe buildings, wandering animals, improper and illicit commercial transactions as well as unwelcome activities of prostitutes and gamblers. ${ }^{14}$ It was a modest but highly visible sign of how the city

\footnotetext{
${ }^{11}$ M. Foucault, Birth of Biopolitics. Lectures at the College de France, 1978-1979, trans. Graham Burchell (New York, 2011), 1-47.

${ }^{12} \mathrm{G}$. Geltner, 'Public health', in S. Blanshei (ed.), A Companion to Medieval and Renaissance Bologna (Leiden, 2018), 103-28; G. Geltner, 'Healthscaping a medieval city: Lucca's Curia viarum and the future of public health history', Urban History, 40 (2013), 395-415; S. Blanshei, Politics and Justice in Late Medieval Bologna (Leiden, 2010), 511-13.

${ }^{13}$ Archivio di Stato di Stato di Bologna, Podestà, Ufficio delle acque, strade, ponti, calanchi, seliciate e fango (henceforth ASB Fango). See Geltner, Roads to Health, 153-5, also for how residents lodged their own complaints, framing them in Galenic terms.

${ }^{14}$ Greci, 'Il controllo della città'; B. Breveglieri, 'Il notaio del fango', Atti e Memorie della Deputazione di Storia Patria per le Province di Romagna, 55 (2005), 95-152; G. Albertani, 'Igiene e decoro: Bologna secondo il registro del "notaio del fango" (1285)', Storia Urbana, 116 (2007), 19-36; G. Albertani, 'Igiene e manutenzione. Il caso di Bologna nei programmi legislativi e nella realtà quotidiana del XIII secolo', in A. Campanini and R. Rinaldi (eds.), Artigiani a Bologna: identità, regole, lavoro, secc. XIIIXIV (Bologna, 2008), 165-86.
} 
invested in enforcing a public health programme. In addition to the regular fango inspections, residents themselves could also complain to the fango notary about hazardous acts or unhygienic conditions in their neighbourhoods, workplaces and public sites. In other words, the regulation and management of the city environment was not just a top-down process but also involved ordinary residents settling disputes privately and, the latter having failed, publicly.

Although dirt masters were hardly the only urban officials to enforce health-related policies, the cache of documents they left is immense. The present article draws on a sample of around 3,500 cases taken from a series spanning just under a century, stretching from 1287 to 1383. It records fango officials undertaking regular inspections of the city streets, infrastructure and markets. When violations were observed, they were noted in a register along with information about the location and details of the offence. These outfits produced dozens of registers for the period under examination, whose locational specificity underpins a spatial analysis of how urban regimes understood and confronted health challenges. The information likewise provides insight into how Galenic principles interacted with the practical pursuit of healthy streets and public spaces in Bologna.

Information extracted from the fango registers illuminates two levels in particular of human activities and decision-making. On the one hand, it is a record of the activities that Bolognese residents were engaged in, such as commerce, animal rearing, the production of goods such as cloth, paper and metal, the disposal of waste and the maintenance of public infrastructures such as wells, drainages and sewages. These processes were filtered through the eyes of fango officials, and thus are subject to a second order of decision-making, namely that of a city administration seeking to document and control what it envisioned as deviant behaviours. With that in mind, this article traces the choices of both Bolognese residents and fango officials, examining in particular how the municipality shifted its conceptions and policing of conceived dangers over this long period. Pursuing this goal also sheds light on how the experience of a healthy city, both physically, socially and morally, varied across the city and in time, for instance by gender, profession and location. Our results indicate that the most pointed change appears to be the shift from violations centred on waste creation and mismanagement (at the end of the thirteenth century) to offences dominated by improper and illicit commercial activities (at the end of the fourteenth century), attesting the changing risks and problems, as well as evolving and flexible conceptions of health.

\section{Historical and demographic context}

Like many Italian cities, Bologna's origins stretch back millennia, to the Etruscan and Roman eras. And it was the Romans who implemented the basic grid pattern of the current city centre as well as constructed sewage and water systems. ${ }^{15}$

\footnotetext{
${ }^{15} \mathrm{~F}$. Bocchi, Atlante Storico delle città italiane. Bologna, I, Da Felsina a Bononia: dalle origini al XII secolo (Bologna, 1995); F. Bocchi, Atlante Storico delle città italiane. Bologna, II, Il Duecento (Bologna, 1996). For an archaeological perspective, see R. Curina, L. Malnati, C. Negrelli and L. Pini (eds.), Alla ricerca di Bologna antica e medievale. Da Felsina a Bononia negli scavi di Via d'Azeglio (Florence, 2010), especially
} 
Thereafter, Bologna developed by expanding and incorporating what were once suburbs into the urban confines. ${ }^{16}$ Roman Bologna was surrounded by a defensive wall, which was expanded during the later Lombard period. ${ }^{17}$ A new set of walls was constructed in the eleventh and twelfth centuries, followed by an additional set in the fourteenth century as the city population grew (see Figure 1). Thanks to excellent demographic information for Bologna, the city's morphology is easily correlated with population growth. Some demographic information can be distilled from local estimi, lists used for tax purposes in which all heads of household recorded their names, debts and property. ${ }^{18}$ These documents were then turned over to city officials, who tended to take them at face value, despite authors' presumable incentive to under-report the size and value of their properties. Finally, estimi were organized by parish. On the basis of these estimi, historians tend to agree that in the late thirteenth century (where our dataset begins), Bologna reached its demographic peak of between 55,000 and 65,000 people, ${ }^{19}$ although the population may have been even larger. ${ }^{20}$ Working in a GIS environment facilitates mapping the number of households in each parish, revealing how the

the sections R. Curina, 'Il condotto idrico e le strutture di età romana: l'organizzazione del suburbio meridionale', 59-71, and C. Negrelli, 'La sequenza insediativa', 15-53. And see J. Ortalli and L. Pini (eds.), Lo scavo archeologico di Via Foscolo-Frassinago a Bologna: aspetti insediativi e cultura materiale (Bologna, 2002); F. Bergonzoni and G. Bonora, Bologna romana, I, Fonti letterarie - Carta archeologica del centro urbano, Fonti per la storia di Bologna (Bologna, 1976).

${ }^{16}$ Other medieval excavations include M. Librenti and C. Negrelli, 'L'Indagine nella chiesa di S. Maria dei Servi e l'archeologia in ambito urbano a Bologna', in R. Fiorillo and P. Peduto (eds.), III Congresso Nazionale di Archeologia Medievale (Florence, 2003), 279-85; S. Gelichi and R. Merlo (eds.), Archeologia medievale a Bologna. Gli scavi nel Convento di San Domenico (Bologna, 1987); S. Gelichi, C. Cavallari and M. Medica (eds.), Medioevo svelato: storie dell'Emilia-Romagna attraverso l'archeologia (Bologna, 2018).

${ }^{17} \mathrm{C}$. DeAngelis and R. Dondarini, Atlante storico delle città italiane. Bologna III, Da una crisi all'altra: (secoli XIV-XVII) (Bologna, 1997), 21-2; M. Librenti and R. Michelini, 'La seconda cerchia di Bologna', in G. Volpe and P. Favia (eds.), V Congresso nazionale di Archeologia Medievale (Borgo San Lorenzo, 2009), 194-9.

${ }^{18}$ R. Smurra, 'Progetto Fonti medievali in rete', Centro Gina Fasoli: www.centrofasoli.unibo.it, accessed 1 Jan. 2019; R. Smurra, 'Fiscal sources: the estimi', in Blanshei (ed.), A Companion, 42-55; R. Smurra, Città, cittadini e imposta diretta a Bologna alla fine del Duecento. Ricerche preliminari (Bologna, 2007). See also M. Giansante, 'Il quartiere bolognese di Porta Procola alla fine del Duecento. Aspetti economici e sociali dell'estimo del 1296-7', Il Carrobbio, 11 (1985), 123-41; D. Micheletti, 'Gli estimi del comune di Bologna il quartiere di Porta Ravennate (1296-97)', II Carrobbio, 7 (1981), 293-304; D. Rocca, 'Gli estimi del Comune di Bologna. Il quartiere di Porta Stiera nel 1296/97', University of Bologna Ph.D. thesis, 1984/ 85; M. Vallerani (ed.), 'Il valore dei cives. La definizione del valore negli estimi bolognesi del XIV secolo', in Valore delle cose e valore delle persone (Viella, 2018), 241-70; R. Dondarini, Bologna medievale. Nella storia delle città (Bologna, 2000); E. Erioli, 'Aspetti demografici della Bologna medievale. Riflessioni metodologiche e prospettive di ricerca', I quaderni del m.x.s., 5 (2017), 23-50.

${ }^{19}$ Smurra, 'Progetto Fonti medievali in rete'; S.K. Wray, Communities and Crisis: Bologna during the Black Death (Leiden, 2009), 62-5; A. Pini, Città medievali e demografia storica: Bologna, Romagna, Italia; (secc. XIII-XV) (Bologna, 1996); A. Pini, 'Problemi di demografi a bolognese del Duecento', Atti e Memorie della Deputazione di Storia Patria per le Province di Romagna, 16-17 (1969), 180-222; R. Dondarini, 'La popolazione del territorio bolognese fra XIII e XIV secolo: stato e prospettive delle ricerche', in R. Comba and I. Naso (eds.), Demografi a e società nell'Italia medievale (Cuneo, 1994), 203-30.

${ }^{20}$ See D. Bortoluzzi, 'Nuove proposte per una stima della popolazione bolognese tra la fine del Duecentro e il 1348', Deputazione di Storia Patria per le Province di Romagna, forthcoming. 


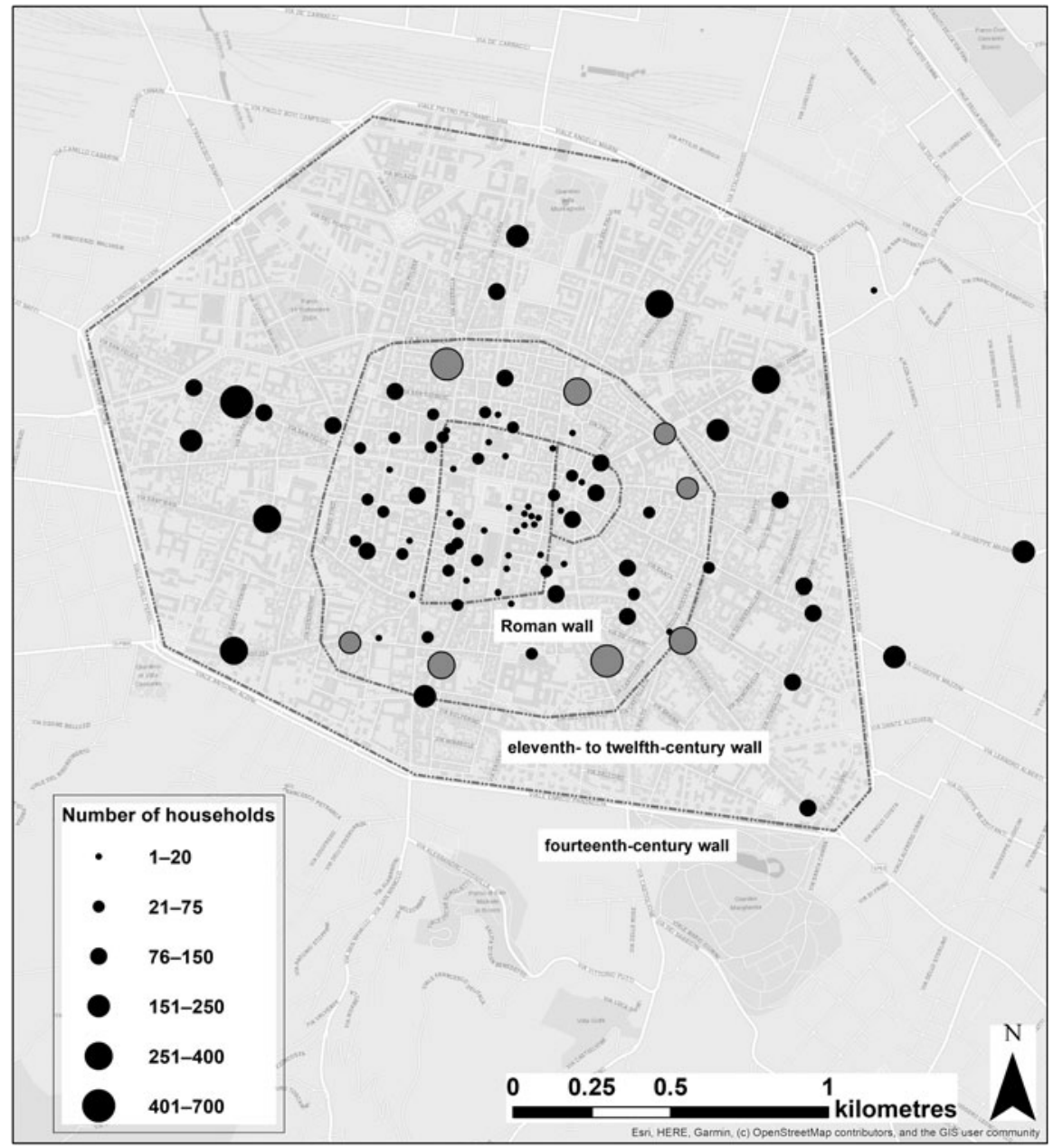

Figure 1. Population distribution in Bologna, 1296

Source: R. Smurra, 'Fiscal sources: the estimi', in S. Blanshei (ed.), A Companion to Medieval and Renassiance Bologna (Leiden, 2018), 45-8; S.K. Wray, Communities and Crisis: Bologna during the Black Death (Leiden, 2009), 266; M. Fini, Bologna sacra: tutte le chiese in due millenni di storia (Bologna, 2007).

population was distributed throughout the city. Figure 1 is based on the 1296 estimo and suggests that most people at that time lived within or around the second ring of walls. The eight churches in grey comprised over 25 per cent of the households listed in the 1296 estimi (parish confines likely included territory on either side of the wall). Still, this suggests that the zone around the second ring of walls was densely populated, with major implications for the cleanliness and hygiene of this sector.

In the middle of the examined period, an epidemic of Yersinia pestis took place, also known as the Black Death (1346-53), which killed somewhere between 40-60 
per cent of western Europe's population, including that of Bologna. ${ }^{21}$ The city continued to function through this major crisis, ${ }^{22}$ enforcing public health measures that were in place well beforehand, as was the case in other Italian cities. ${ }^{23}$ Indeed, and as we will argue below, environmental health and urban cleanliness were constant concerns of local residents and officials well before the epidemic's onset. This points to a long-standing and sophisticated understanding of health and the ability to foresee risks and implement solutions, in response to pressures on the urban infrastructure rather than merely react to cataclysms. At any rate, mapping archival and other data suggests that the scope of this office and the activities with which it was concerned shifted over time due to a mixture of events and processes that is not always possible to pin down.

\section{Mapping fango registers}

Fango notaries recorded a description of the offence and location, the gender and profession of the offender, the offender's residence and legal actions rendered. The registers date from various years between 1287 to 1383 , yet are unequally distributed chronologically. This mostly reflects the extant volumes' illegibility around the middle decades of the fourteenth century, rather than any lack of activity in this period, although almost no records survive from the immediate Black Death era. ${ }^{24}$ While extracting data from the extant and most legible registers, information was divided into three time baskets: 1287-1323, 1330-47 and 1355-83. The division sought to balance between the years present and number of cases for each year, yet in a manner that would allow for an analysis of health and regulatory practices before and after the plague. From 1287 to 1323, the most legible registers survive from eight calendar years: 1287, 1298-1301, 1309, 1317 and 1323. From 1330 to 1347 , registers were selected for legibility from 10 years: $1330-35,1337,1342$, 1345 and 1347. Finally, from 1355 to 1383 registers from 9 years were similarly chosen: $1355,1357,1360-61,1369,1378-79$ and 1382-83. This fairly equal distribution of years, however, contrasts with an unequal spread of cases; the dataset contains 1,952 incidents in the first period, 370 in the second, 1,207 in the third and 11 undated records (see Appendix). These include both cases inside and

\footnotetext{
${ }^{21}$ Overviews for Europe include O. Benedictow, The Black Death 1346-1353: The Complete History (Woodbridge, 2000); R. Horrox (ed.), The Black Death (Manchester, 1994); S. Cohn, The Cult of Remembrance and the Black Death: Six Renaissance Cities in Central Italy (Baltimore, 1992); M. Green (ed.), Pandemic Disease in the Medieval World; Rethinking the Black Death (Kalamazoo, 2015). For the population of Bologna during this period, see R. Greci and A. Pini, 'Una fonte per la demografia storica medievale: le "Venticinque" bolognesi (1247-1404)', Rassegna degli archivi di Stato, 36 (1977), 337-417; A. Pini, 'Forme di conduzione, rendita fondiaria e rese cerealicole nel Bolognese dopo la peste del 1348: l'azienda del convento di San Domenico', in V. Fumagalli and G. Rossetti (eds.), Medioevo rurale: sulle tracce della civiltà contadina (Bologna, 1980), 259-97.

${ }^{22}$ Wray, Communities and Crisis, 99-146.

${ }^{23}$ Geltner, Roads to Health; G. Geltner, 'The path to Pistoia: urban hygiene before the Black Death', Past \& Present, 246 (2020), 3-33.

${ }^{24}$ ASB Fango registers in this sample are as follows, with the number of records from each year in parentheses: 1287 (342), 1298 (189), 1299 (47), 1300 (143), 1301 (564), 1309 (237), 1317 (382), 1323 (48), 1330 (11), 1331 (14), 1332 (49), 1333 (80), 1334 (52), 1335 (84), 1337 (34), 1342 (1), 1345 (8), 1347 (37), 1355 (3), 1357 (7), 1360 (2), 1361 (370), 1369 (306), 1378 (144), 1379 (282), 1382 (49), 1383 (44) and loose records $1286-1370(11)$.
} 
outside the city, with the former type much more prominent. In total there are 3,540 records, of which 2,262 could be assigned to a specific parish, piazza or street in the city of Bologna. All other entries did not record location or recorded an ambiguous one; the latter records were not mapped but still were included in the table analyses below.

Allegations made in the recorded cases were classified under 10 broad categories: (1) animals - illicit presence of non-human animals; (2) building violation - an improper or risky construction; (3) blockage - physical impediment to streets, porticos or drains; (4) commerce - products sold in bad faith or of poor quality, or products sold off-site or off-hours and thus unsupervised; (5) damage - intentional destruction of buildings or property; (6) filth - leaving refuse in illicit areas, keeping faulty and exposed latrines and their drains; (7) gambling - playing prohibited games considered a moral pollution; (8) neglect - failure to maintain infrastructure; (9) prostitution - another form of moral pollution; and (10) safety - usually unsupervised or overloaded carts in a public area.

Among the latter, three types of offences in particular were perceived as hazardous to people's physical health, namely blockage, filth and neglect. All of them were believed to put people in harm's way, by causing miasma and/or rendering certain sites more dangerous due to limited circulation or increasing risks of ocular intromission. There is some overlap between the three categories, although we tried to remain consistent with our sometimes-arbitrary allocations. Thus, for example, poorly maintained drains and wells were classified as a form of neglect, while dirt in front of a residence fell under the category of blockage, and dung found near a well was counted as a filth violation. At any rate, from a Galenic perspective, all of these offences would have had a proclivity for generating miasmas emerging from stagnant water or waste out in the open, or by presenting passers-by with dangerous sights such as rotting carcasses. Thus, for the spatial analysis in GIS, the records for these three categories were amalgamated and the combined number mapped for each of the three periods.

The second main strand of analysis concerned the location and density of commercial offences. Commercial offences dominated fango violations for the last period under examination, and it is clear that ensuring a vibrant and properly regulated economy was also a major concern of urban officials, part of their overall conception of a healthy city. ${ }^{25}$ Whatever other claim they may support, these offences' common detection underscores that fango officials in Bologna understood the importance of keeping streets, public spaces and water sources free and clean of waste, and limiting dishonest and unscrupulous commercial transactions. Enforcing preventative regulations was not just a matter of civic pride, but an issue perceived as directly impacting the wellbeing and the functioning of the urban environment. ${ }^{26}$

\footnotetext{
${ }^{25}$ R. Rinaldi (ed.), 'Una città di mercati', in Nella città operosa: Artigiani e credito a Bologna fra Duecento $e$ Quattrocento (Bologna, 2016), 11-56. For the distribution of artisans and commercial activities, see C. Arnaud, Topographien des Alltags Bologna und Straßburg um 1400 (Berlin, 2018); and C. Arnaud, 'Mapping urban communities. A comparative topography of neighbourhoods in Bologna and Strasbourg in the late Middle Ages', in J. Colson and A. van Steensel (eds.), Cities and Solidarities: Urban Communities in Pre-Modern Europe (New York, 2017), 60-78.

${ }^{26}$ For a discussion, see Geltner, Roads to Health.
} 


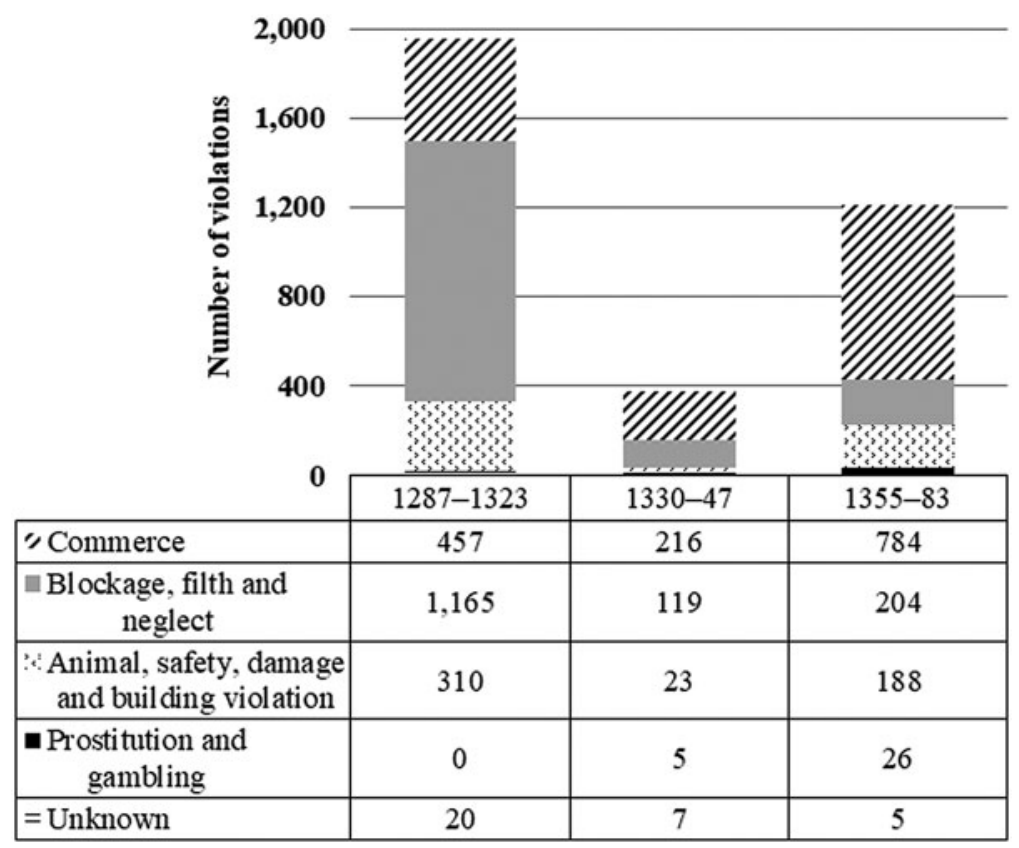

Figure 2. Fango violations by period

Note: The data here are presented for the first time in this article, extending the work of G. Geltner, Roads to Health: Infrastructure and Urban Wellbeing in Later Medieval Italy (Philadelphia, 2019).

Source: Archivio di Stato di Stato di Bologna, Podestà, Ufficio delle acque, strade, ponti, calanchi, seliciate e fango (henceforth ASB Fango).

The data also underscore a dynamic process. As the Appendix and Figure 2 suggest, recorded offences change markedly over time. In particular, there are far more violations, in the first period, from 1287 to 1323 , that relate to waste mismanagement, than in later periods (1,165 in period 1, 119 in period 2 and 204 in period $3)$. In fact, in period 1, nearly 60 per cent of all recorded fango violations concern waste production or mismanagement (the combination of blockage, filth and neglect). By contrast, in the two later periods, approximately 60 per cent of the allegations involve commerce, indicating a shift in the kinds of offences that were being reported. Whatever their focus, it is clear that concerns about urban hygiene and environmental cleanliness predate the Black Death's onset.

Figure 2 represents the fines meted out by fango officials in each of the three time baskets, highlighting the office's changing focus from offences related to the creation and mismanagement of waste to commercial regulation. The shift is hard to explain, although decreased attention to waste disposal violations may echo some scholars' suggestion that the local sewage system was covered over between the first and second periods. ${ }^{27}$ This would have dramatically changed waste disposal practices, or at least their spatial profile as regards policing, given

\footnotetext{
${ }^{27}$ C. Ghirardacci, Della historia di Bologna: parte terza, ed. A. Sorbelli (Città di Castello, 1912-32); L. Sabbionesi, "Pro maiore sanitate hominum civitatis...et borgorum": lo smaltimento dei rifiuti nelle città medievali dell'Italia settentrionale', Università Ca' Foscari Ph.D. thesis, 2016, 250-8; F. Bocchi,
} 


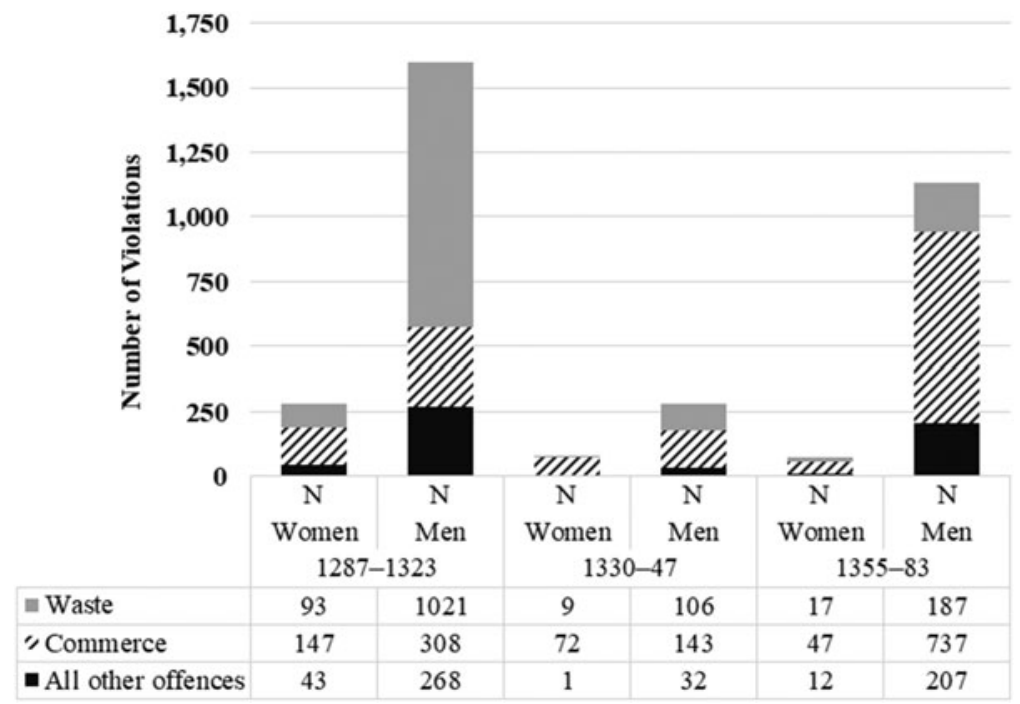

Figure 3. Distribution by gender Source: ASB Fango.

that covered sewers would reduce violations for previously unsealed channels, ditches and latrines, which from a Galenic point of view were especially hazardous, both as miasma generators and sites for ocular intromission. More importantly, the system's overhaul underscores the city officials' ability to recognize dangers to the city and to implement solutions at the population level. At any rate, the shift from waste creation and mismanagement citations to violations centred on commercial activities is worth exploring.

Beyond the improvements made to the canal and drainage system, it may also point to evolving or changing paradigms of health management and urban risks. Conceptions and enactments of health are and were dynamic, and it is unsurprising that city officials would rethink how they regulated their city or where they focused their efforts with limited resources at their disposal. To this end, analysing data in GIS reveals changes in violation types, in the profiles of the offenders (profession and location) and the locations in which city officials concentrated. All of these are mapped, quantified and explored in the next section.

\section{Gender and profession in the fango charges}

Both policing activities and residents' (mis)behaviour participated in the cultural reproduction of social categories and as such they disclose gender disparities in number and type of violations (see Figure 3). Broadly speaking, men are more frequently cited than women for all charges throughout the subperiods and, notably, males received the majority of citations for waste charges (the combination of blockage, filth and neglect). On the other hand, women are most often denounced

'Gestione delle acque e politica delle infrastrutture a Bologna all'inizio dell XIII secolo', in C. Travaglini (ed.), La città e il fiume: secoli XIII-XIX (Rome, 2008), 23-9; Bocchi, Il Duecento, 21. 
for commerce-related violations, that is illicit or improper sales; the category comprises over 50 per cent of citations for women in all periods, underscoring their significant involvement in that sector, which is otherwise sometimes difficult to document. $^{28}$

Fango officials not only altered the kinds of violations they policed, but also shifted their focus in terms of those whom they cited, as can be seen in Table 1 . The pattern holds for both waste violations as well as commercial violations, once again spotlighting evolving conceptions of health and risk among city officials. In the beginning of the period under study, the top-cited professions for waste violations were ministeriales (elected parish officials), sellers of ready food, meat and fish mongers and vendors and grocers. Yet by the later fourteenth century, officials all but disappear, accompanied by the preponderance of taverners and innkeepers, metalworkers, as well as cloth manufacturers and sellers. Within this admittedly limited sample, accused professionals tended to be male.

Meat and fish mongers alongside vendors and grocers continued to be policed in both periods. The focus on butchers and meat workers is unremarkable, particularly since their activities carried major pollution risks from a humoral perspective and as such were heavily regulated in the Bolognese statutes throughout the thirteenth and fourteenth centuries. ${ }^{29}$ Similar hygienic risks were thought to be attendant upon artisans such as metalworkers and cloth manufacturers, whose work polluted the air. To a significant extent, therefore, the focus on workshops can be said to reflect (and in any case agrees with) Galenic medical principles. ${ }^{30}$

Evidence for the dirt masters' shifting gaze emerges likewise from examining commercial violations. In particular, the sample suggests that the city officials changed their focus from vendors and grocers to taverners and innkeepers, and to a lesser extent meat and fish sellers (see Table 2). One notable point is the involvement of women, particularly female vendors and grocers, who constitute over 25 per cent (122 of 457 cases) of those held responsible for commerce violations. Indeed, this group of occupations seems to be heavily female in both the first and second periods (almost triple and double their male counterparts, respectively), suggesting that women pursuing such trades in the public eye endured heavier scrutiny than men. It is entirely possible, of course, that the comparatively high degree to which those women were scrutinized reflected officials' class and not only gender bias, or that the specific products sold by those women in particular were considered strategic. The registers, however, do not provide such information, but it is unlikely that gender played little or no role in such cases, also given that produce stalls could often be owned and operated by a married couple, in which case allegations launched specifically at the female counterpart are telling. At any rate, by the end of the period, policing shifted from food vendors to the regulation of more male-dominated professions including taverners and innkeepers, as well as stricter regulation of butchers. Still, female food vendors continue to make an appearance in fango records throughout the analysed period, albeit in diminished numbers by its end.

\footnotetext{
${ }^{28}$ D. Romano, Markets and Marketplaces in Medieval Italy c. 1100 to c. 1440 (London, 2015).

${ }^{29}$ L. Frati (ed.), Statuti di Bologna dall'anno 1245 all'anno 1267, 2 vols. (Bologna, 1869-77); G. Fasoli and P. Sella (eds.), Statuti di Bologna dall'anno 1288, 2 vols. (Vatican City, 1937-39).

${ }^{30}$ Geltner, Roads to Health, 96-105.
} 
Table 1. Waste violations and profession distribution

\begin{tabular}{llll}
\hline Professional category & Period 1 & Period 2 & Period 3 \\
\hline Ministeriales (elected parish officials) & 31 & 0 & 2 \\
Food preparers & 13 & 0 & 1 \\
Meat and fish sellers & 12 & 3 & 18 \\
Vendors, merchants, grocers, spice/wine sellers & 10 (6 women) & 0 & 11 (1 woman) \\
Servants and carters & 4 (3 women) & 0 & 2 (1 woman) \\
Metalworkers & 0 & 0 & 9 \\
Wood workers & 3 & 0 & 5 \\
Leather and fur workers & 2 & 1 & 0 \\
Cloth workers and sellers & 1 & 1 & 8 \\
Medical professionals & 1 & 6 & 1 \\
Taverners and innkeepers & 1 & 3 & 0 \\
Soldiers and prison guards & 3 & 1 & 0 \\
Priests and rectors & 1 & 1 & 0 \\
Parchment makers & 0 & 5 & 3 \\
Miscellaneous professionals & 1 & 0 & 0 \\
Miscellaneous residents & 3 & 3 & 73 \\
Total & 86 & 24 & \\
\hline
\end{tabular}

Source: ASB Fango.

Table 2. Commercial violations by profession and gender

\begin{tabular}{|c|c|c|c|c|c|c|}
\hline \multirow[b]{2}{*}{ Professional category } & \multicolumn{2}{|c|}{ Period 1} & \multicolumn{2}{|c|}{ Period 2} & \multicolumn{2}{|c|}{ Period 3} \\
\hline & Men & Women & Men & Women & Men & Women \\
\hline Vendors, grocers, spice/wine sellers, shopkeepers & 41 & 122 & 35 & 62 & 21 & 23 \\
\hline Taverners and innkeepers & 60 & 8 & 15 & 1 & 312 & 5 \\
\hline Meat and fish sellers & 6 & 0 & 9 & 3 & 48 & 0 \\
\hline Food preparers & 13 & 1 & 15 & 0 & 5 & 0 \\
\hline Wood workers & 4 & 0 & 4 & 0 & 0 & 0 \\
\hline Leather and fur workers & 0 & 1 & 0 & 0 & 0 & 0 \\
\hline Cloth workers and sellers & 0 & 0 & 0 & 0 & 21 & 0 \\
\hline Metalworkers & 0 & 0 & 0 & 0 & 24 & 0 \\
\hline Servants and carters & 2 & 1 & 0 & 0 & 8 & 0 \\
\hline Candle and wax makers/sellers & 2 & 0 & 7 & 0 & 0 & 0 \\
\hline Parchment makers & 0 & 0 & 0 & 0 & 2 & 0 \\
\hline Lime sellers & 0 & 0 & 2 & 0 & 1 & 0 \\
\hline Miscellaneous professionals & 0 & 0 & 1 & 0 & 2 & 1 \\
\hline Total & 128 & 133 & 88 & 66 & 444 & 29 \\
\hline
\end{tabular}

Source: ASB Fango.

\section{Distribution of violations across the city}

Figures $4 \mathrm{a}, \mathrm{b}$ and $\mathrm{c}$ display the density and location of waste-related violations, using the kernel density feature in ArcMap for each of the three periods. This spatial function highlights dense clusters of offences, facilitating a comparison of how the number and location of waste violations shifted over time. During the first period, offences relating to waste production and mismanagement are fairly ubiquitous - there are clusters in the city centre, which housed the major markets, and around the edges of the second ring of walls. Recall that there was a ditch or canal associated with this structure, where waste could have been easily (if illicitly) dumped. 

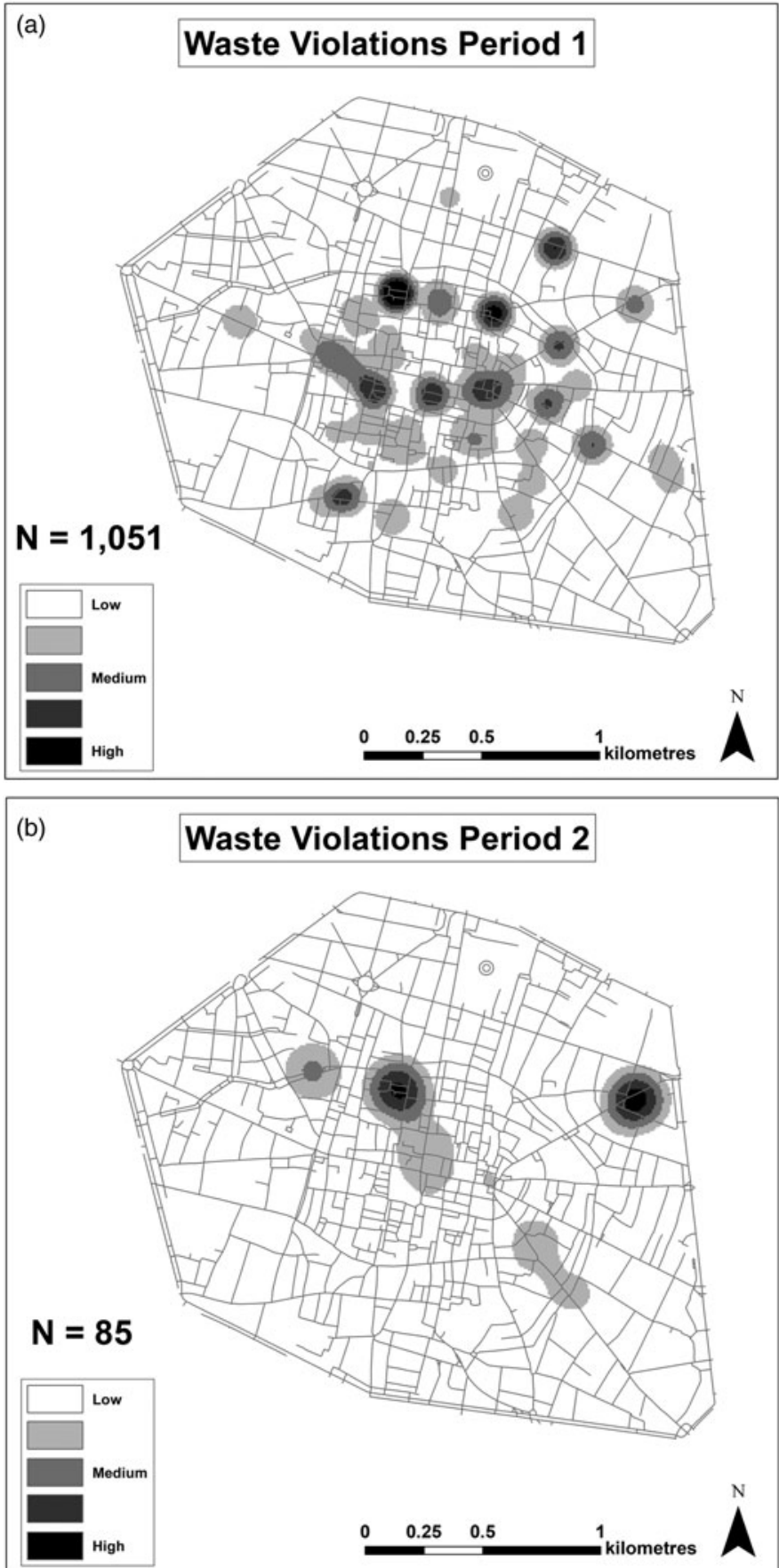

Figure 4. Density of waste production and mismanagement offences 1287-1383 Source: ASB Fango. 


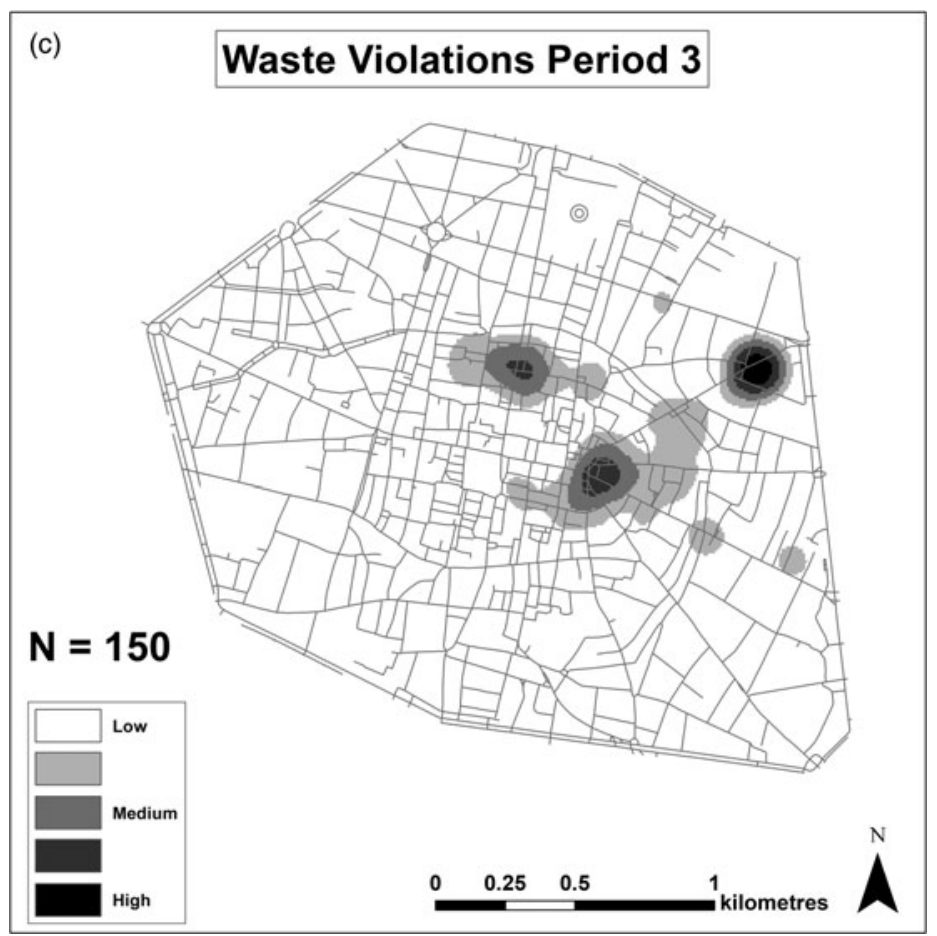

Figure 4. Continued

Waste concentrations around the second ring of walls were also a product of urban expansion. During this period, the city was in the process of dismantling its second ring of walls as it was constructing a third, and it appears that waste and construction debris were used to fill the nearby ditch. ${ }^{31}$ In sum, while illicit waste disposal in public space regularly drew officials' attention and preventative action, it was a fact of life in Bologna. However, by the second period, waste disposal violations sharply declined, and there are only two clusters of offences, namely to the north and east of the city, a trend that continues into the final period.

The geographical shift was accompanied by an overall reduction in this category of allegations, as mentioned before. In the period 1287-1323, the number of waste disposal allegations is approximately 10 times those of the subsequent periods, a trend attributable at least in part to the gradual covering of the city's sewage system, itself a preventative intervention in line with Galenic principles. Another possible explanation is the population's decline. The Black Death took place between the second and third periods examined, effectively halving Bologna's population, notwithstanding ongoing urban migration. Fewer inhabitants may have thus produced less waste or else had greater recourse to under-supervised areas where they could dispose of it unchallenged. The decrease in waste-related violations, however,

\footnotetext{
${ }^{31}$ R. Dondarini and C. De Angelis, Atlante Storico delle città italiane. Bologna, III, Da una crisi all'altra (secoli XIV-XVII) (Bologna, 1996), 11-21.
} 
predates the plague, although it is hard to draw a firm conclusion given that the second period has a small sample size. By the final period, at any rate, commerce and safety allegations comprise approximately 80 per cent of cases (as opposed to 23 per cent in the first period), suggesting that there was a shift in the conception of health threats, which led to more intensive policing of the products that people could buy and sell. Thus, the officials altered their focus from waste offences to offences related to commerce, while ostensibly retaining a Galenic view in that it was necessary to regulate and control the flow of people and goods in order to ensure the city's dynamic balance.

Archival sources concerning preventative interventions can be supplemented by archaeological evidence, including the city's defences and canal network, as well as by examining the city's general topography. The second set of walls, gradually dismantled in favour of a third ring and flanked by a ditch or canal, seems to have constituted a zone in which much waste was dumped. ${ }^{32}$ The canal system had both productive as well as waste-removal purposes, as water flowed through the city from south to north, and from the centre towards the outskirts. ${ }^{33}$ Both infrastructures and their upkeep accordingly had significant implications for creating waste sinks and which neighbourhoods bore this environmental burden. Thus, while city officials were clearly concerned with waste disposal and made considerable efforts to curb practices perceived as polluting neighbourhoods or blocking ideal flows of input and output, they also had to contend with limited resources. Officials working to limit practices they saw as potentially dangerous faced tens of thousands of people, not to mention numerous non-human animals, and probably focused on the practices they felt to be most problematic, visible or easy to enforce.

\section{The regulation of commerce by fango officials}

Rather than pursuing physical cleanliness as an independent goal, Bolognese officials saw it as an integral part of maintaining the city's moral and social order. As we have seen, dirt masters also regulated numerous commercial activities, constantly denouncing improper and illicit transactions or those made in bad faith. This aspect of urban policing too evolved throughout the period under examination, in the neighbourhoods and spaces city officials chose to monitor.

\footnotetext{
${ }^{32}$ For archaeological overviews of medieval waste disposal, see Sabbionesi, "'Pro maiore sanitate", 39-93; and S. Gelichi, 'L'eliminazione dei rifiuti nelle città romane del nord Italia tra antichità ed alto medioevo', in X. Raventós and J. Vallverdú (eds.), Sordes urbis: la eliminación de residuos en la ciudad romana: actas de la Reunión de Roma (15-16 de noviembre de 1996) (Rome, 2000), 13-23; Bocchi, 'Gestione delle acque', 23-9.

${ }^{33}$ S. Cremonini and E.A. Bracci, 'Problemi di paleoidrografia in ambito urbano. Bologna: rassegna critica di ipotesi e nuovi dati', in Curina, Malnati, Negrelli and Pini (eds.), Alla ricerca di Bologna antica e medievale, 167-76; S. Cremonini, 'Il quadro geopedologico. Indicazioni sull'evoluzione geomorfologica del pedecolle e del centro storico di Bologna negli ultimi 3.000 anni', in Ortalli and Pini (eds.), Lo scavo archeologico, 119-41; S. Cremonini, 'Il torrente Savena oltre i limiti dell'analisi storica. Un esempio di archeologia fluviale', Atti e Memorie della Deputazione di Storia Patria per le Province di Romagna, 42 (1991), 159-205; A. Zanotti, Il sistema delle acque a Bologna dal XIII al XIX secolo (Bologna, 2000), 2384; A. Calbi, Acquedotto 2000: Bologna, l'acqua del duemila ha duemila anni (Bologna, 1985); G. Gottardi, A. Bugini, S. Camprini and M. Manferrari, 'Aspetti della tradizione scientificio-tecnica idraulica bolognese', in M. Fontana (ed.), Bologna e l'invenzione delle acque: saperi, arti e produzione tra '500 e '800 (Bologna, 2001), 38-101.
} 
Generally speaking, in the later thirteenth century, fango officers were more heavily focused on the activities of vendors and grocers. Yet, by the later fourteenth century, their targets were more likely innkeepers and taverners; the number of innkeeper and taverner allegations increased nearly fivefold, from 68 in the later thirteenth century to 317 by the end of the fourteenth (see Table 2).

One way to understand this shift is by postulating changing conceptions of risk, since both vendors and grocers (who sold foodstuffs in the marketplace), as well as taverners and innkeepers (responsible for lodging, meat and wine sales), could present physical health risks by selling spoiled products and failing to maintain their facilities. But they also could promote moral dangers through improper sales, or in the case of taverners and innkeepers, occasion drunkenness or rowdy and impious behaviour such as prostitution or gambling. ${ }^{34}$

The difference in policing foci between 1287 and 1383 emerges clearly by sequencing their locations chronologically on the city's map (see Figure 5 and Table 3). In the later thirteenth century, one third of all violations (153) took place in one of three market spaces: Piazza Maggiore (114), Porta Ravennate (28) and Campo del Mercato (11), with the violations in Piazza Maggiore far outweighing the others. The Piazza Maggiore and Porta Ravennate markets were in the city centre, while Campo del Mercato was located in the north.

The fango officials were clearly very concerned about regulating the commercial activities that took place within and around the markets in the first period. However, by the later fourteenth century, the records contain less citations around the markets, and instead shift to the south and eastern part of the city. Allegations in the later periods are also more dispersed, with the highest number of allegations in any one parish numbering 23, a strong decline compared with 114 violations in Piazza Maggiore during the first period.

\section{Gender and commercial activity in Bologna}

The fango registers not only reveal the gaze of the city administration, but also provide considerable insight into the activities and movements of the charged people themselves. For instance, there are notable differences in the ways in which men and women moved around the city and the spaces in which they conducted their everyday activities. One such pattern emerges as regards commercial activities. As mentioned above, while women make up a decreasing number of fango citations across the registers, they were often involved in commercial activities as vendors. There were, moreover, striking differences in the locations in which women and men conducted allegedly illegal transactions. Most women's commercial violations are denounced in Piazza Maggiore. Women are listed as the offenders for 266

\footnotetext{
${ }^{34} \mathrm{M}$. Vise, 'To the Podesta or the Inquisitor?: adjudicating violence against God in Bologna, 1250-1450', in S. Blanshei (ed.), Violence and Justice in Bologna 1250-1700 (Lanham, MD, 2018), 187-206; Blanshei, Politics and Justice, 19-20; T. Dean, Crime and Justice in Late Medieval Italy (Cambridge, 2007), 84-94; G. Roberts, Police Power in the Italian Communes, 1228-1326 (Amsterdam, 2019), 189-90; M. Vallerani, "Giochi di posizione" tra definizioni legali e pratiche sociali nelle fonti giudiziarie bolognesi del XIII secolo', in G. Ortalli (ed.), Gioco e giustizia nell'Italia di Comune (Treviso, 1993), 13-34; F. Pucci Donati, Luoghi e mestieri dell'ospitalità nel Medioevo: alberghi, taverne e osterie a Bologna tra Due e Quattrocento (Spoleto, 2018).
} 


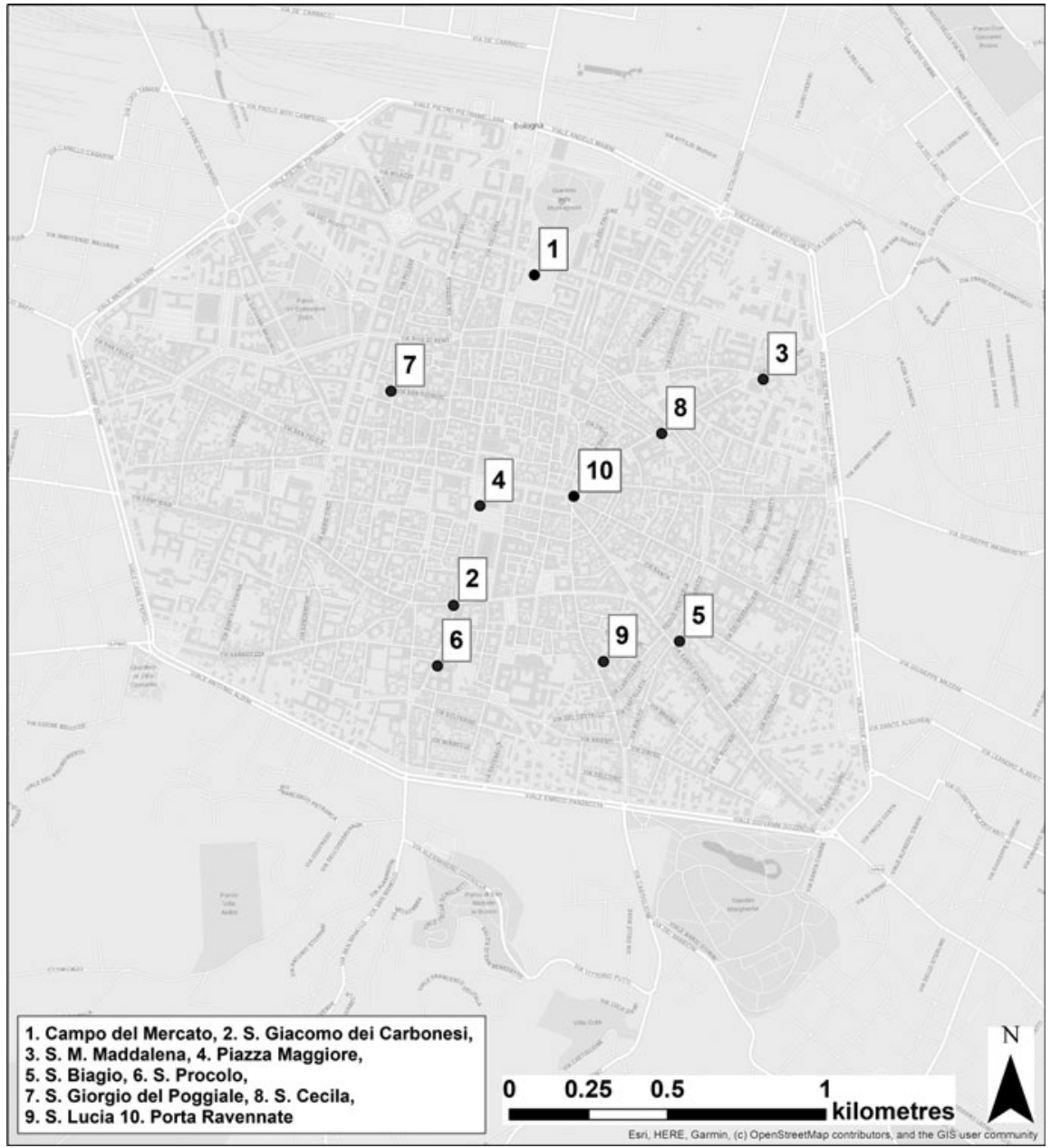

Figure 5. Commercial charge locations Source: ASB Fango.

Table 3. Greatest number of commercial charges per location (N)

\begin{tabular}{lrlr}
\hline Period 1 & & \multicolumn{2}{c}{ Period 3} \\
\hline Piazza Maggiore & 114 & S. Lucia & 23 \\
Porta Ravennate & 28 & S. Cecila & 22 \\
Campo Mercato & 11 & S. Giorgio del Poggiale & 19 \\
& & S. Procolo & 16 \\
& & Piazza Maggiore & 13 \\
& S. Biagio & 13 \\
& S. M. Maddalena & 12 \\
& & S. Giacomo dei Carbonesi & 11 \\
\hline
\end{tabular}

Source: ASB Fango. 
commercial violations during our analysis period. Of these, 219 have specified locations, and nearly 75 per cent took place in Piazza Maggiore. Men's commercial allegations display a different pattern. There are 1,188 commercial allegations attributed to men, of which 551 have a specified location that could be mapped. Of the latter group, less than 10 per cent were recorded in Piazza Maggiore (see Figures $6 \mathrm{a}-\mathrm{f}$ ). One way to explain the disparity is that women - especially lowerclass women - were more heavily scrutinized in centralized marketplaces, which is ironically where they were more likely to work legitimately, a factor that played a smaller role for men. At any rate, women's appearance in the fango records of the last period declined, as officials shifted their focus from the market towards the more male-dominated taverns and inns farther away from the centre.

The available sources do not directly account for the latter shift. It may reflect the dirt masters' choice to target inns and taverns since, as points of consumption, they were more efficiently policed both in terms of product quality (including weights and measures) and immoral behaviour such as gambling, drunkenness and prostitution. ${ }^{35}$ It is also possible that an internal or even casual decision was taken by the city council to update the division of labour within the administration. It would have left monitoring the market to the podestà's famiglia, while the dirt masters would be tasked with policing behaviours and food quality. It may also be the case that city officials began to trust market vendors (often not incorporated in guilds) to regulate themselves, or else feared that officials' constant presence would deter the flow of goods. Finally - and this too remains to be explored - factors of seasonality and adjusted amount of fines could have drawn dirt masters away from markets and into neighbourhood taverns, for instance when young wine was coming into town during the autumn, and old wine had to be quickly consumed. But to repeat, these are merely possibilities, however logical, whose explicit rationale cannot as yet be drawn from the written sources.

In summary, spatial analysis in GIS reveals the dynamic nature of health policing, processes that are hard to detect by identifying environmental factors or documentary analysis alone. Tracing the location and type of offences cited by fango officials in this way provides a unique insight into how earlier urban officials conceived of health risks and implemented protocols to mitigate them. Fango data show that the city administration was attuned to the changing hazards of urban life, over a half-century before the outset of the Black Death. Officials shifted their attention over the course of this period from violations based on infrastructure failure and waste neglect to more commercially oriented citations. They also altered their spatial focus from market violations to more peripheral zones of the city, in lockstep with the city's changing morphology and population density.

\section{Conclusion: pre-modern healthscaping revisited}

Bolognese fango officials are unique for their abundance of surviving records which, in combination with other written and material sources, undergird the foregone analysis. Elsewhere across the peninsula, however, scores of similar, if more thinly documented outfits laboured to build and protect urban environments, informed

\footnotetext{
${ }^{35}$ Dean, Crime and Justice, 88-92; Roberts, Police Power, 18.
} 

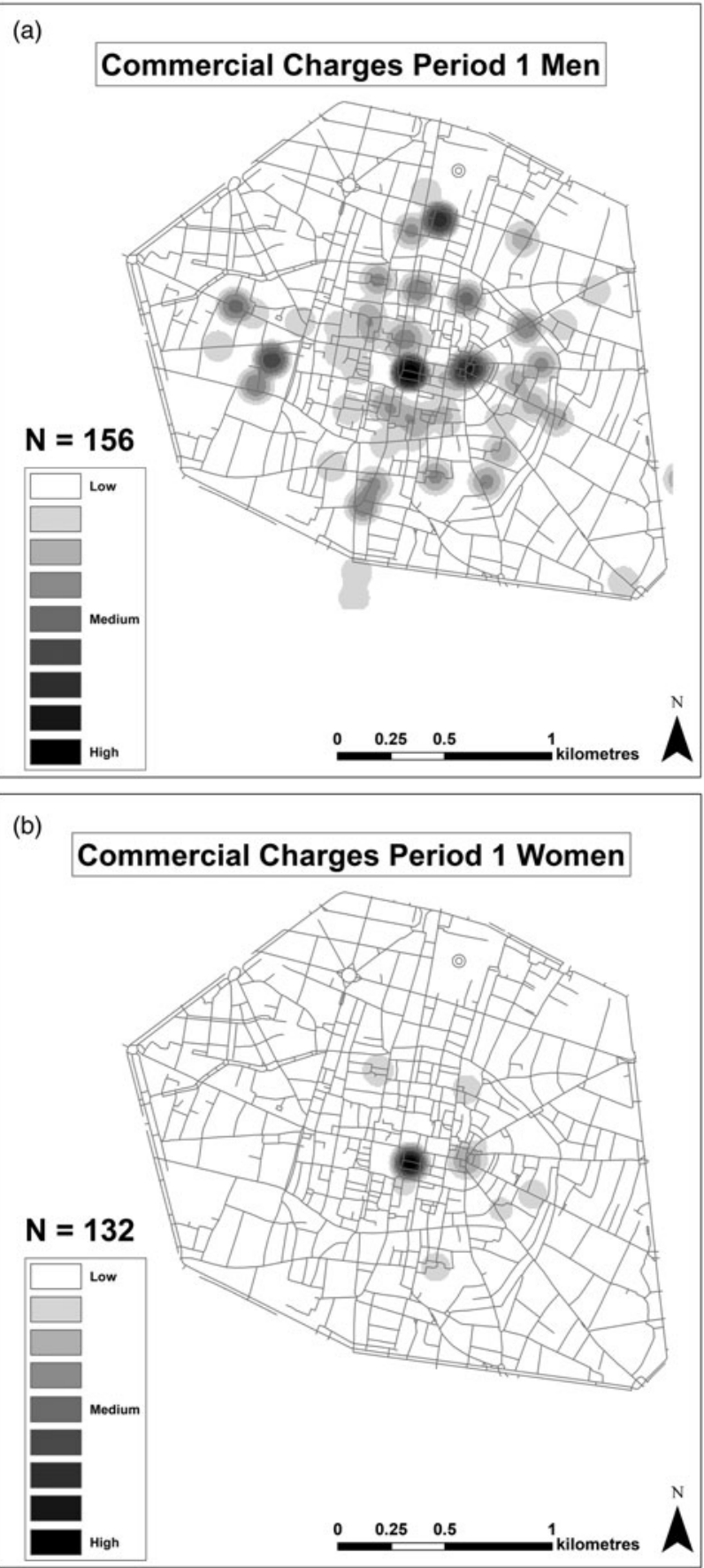

Figure 6. Commercial charges Source: ASB Fango. 


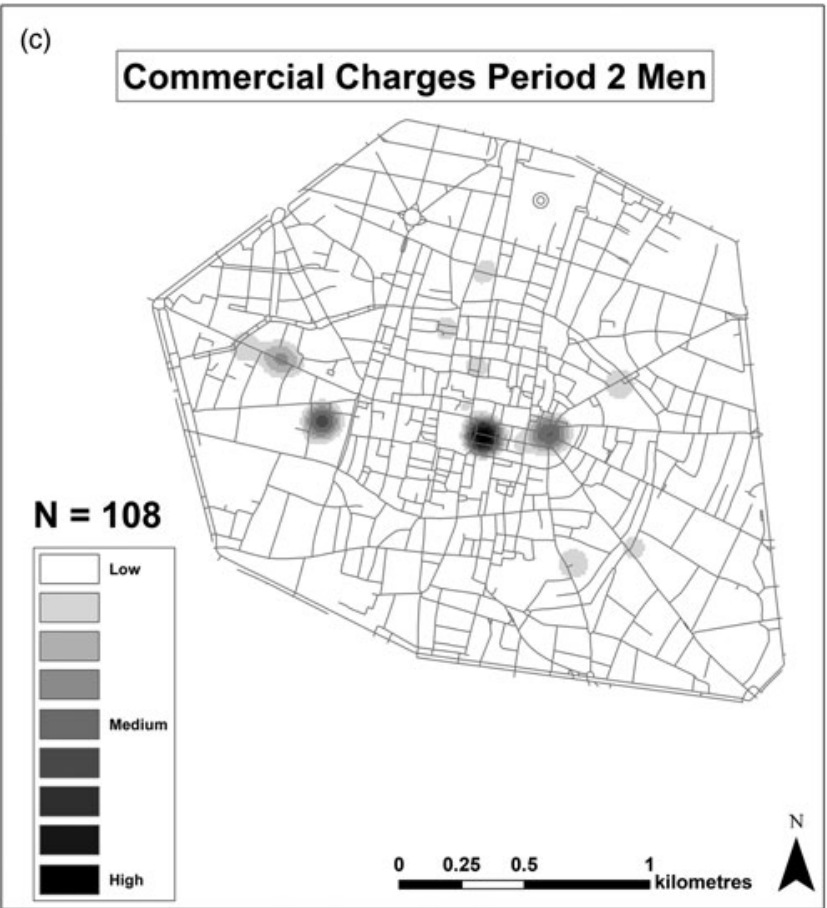

(d)

\section{Commercial Charges Period 2 Women}

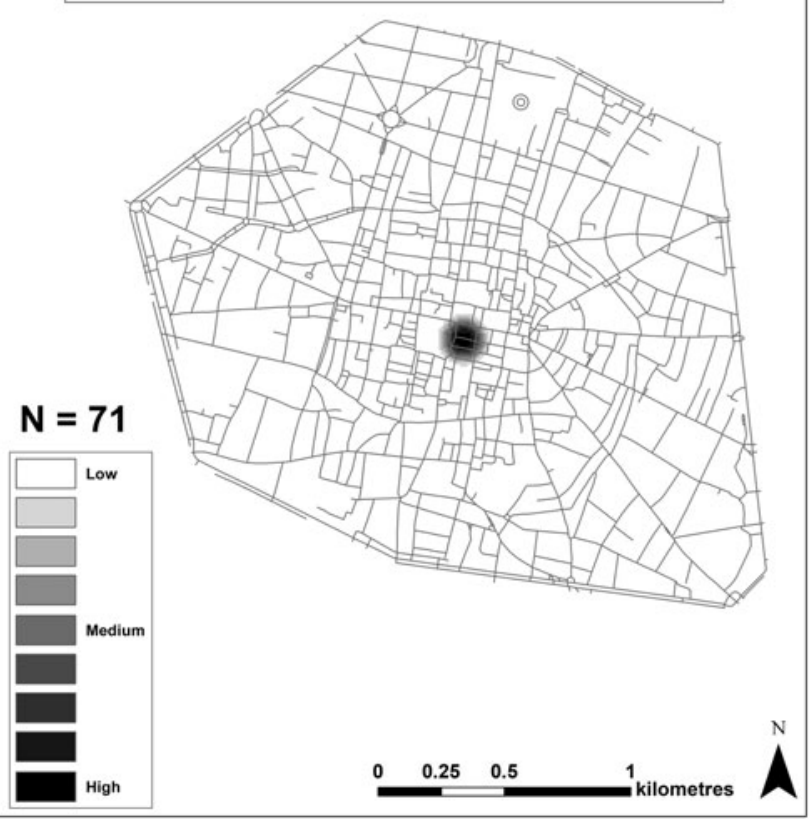

Figure 6. Continued 
(e)

\section{Commercial Charges Period 3 Men}

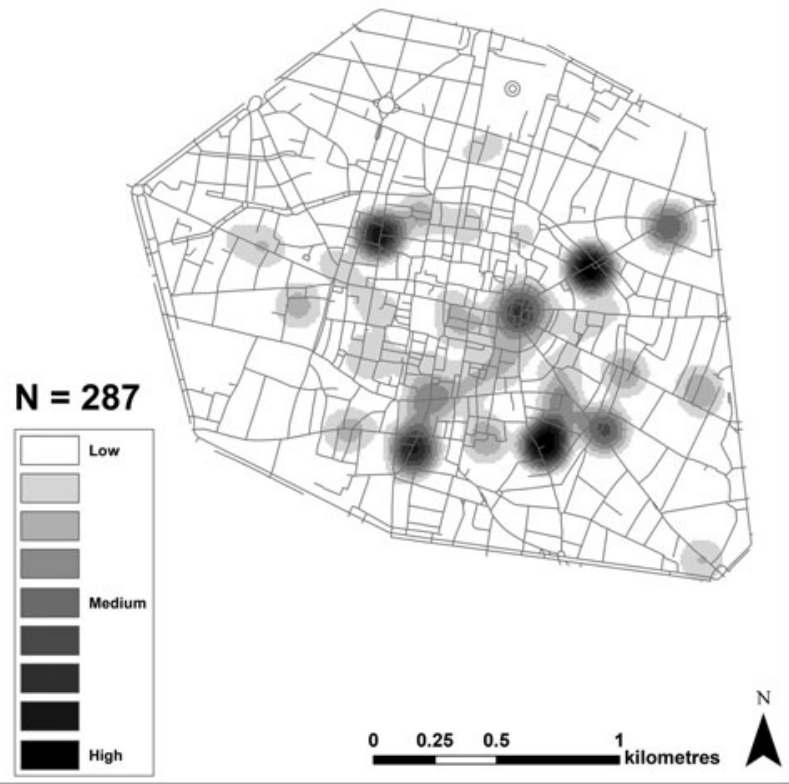

(f)

\section{Commercial Charges Period 3 Women}

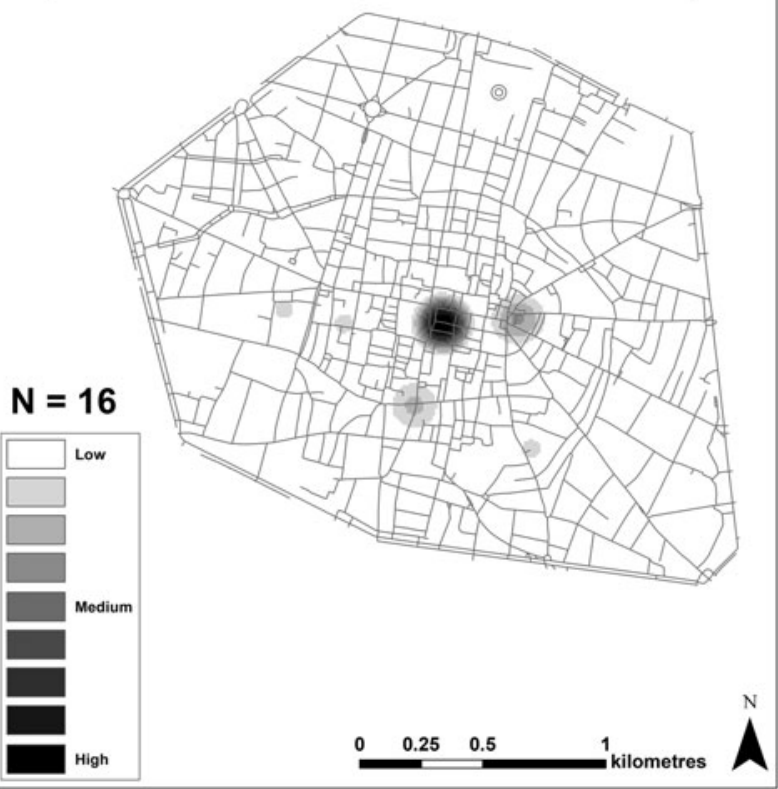

Figure 6. Continued 


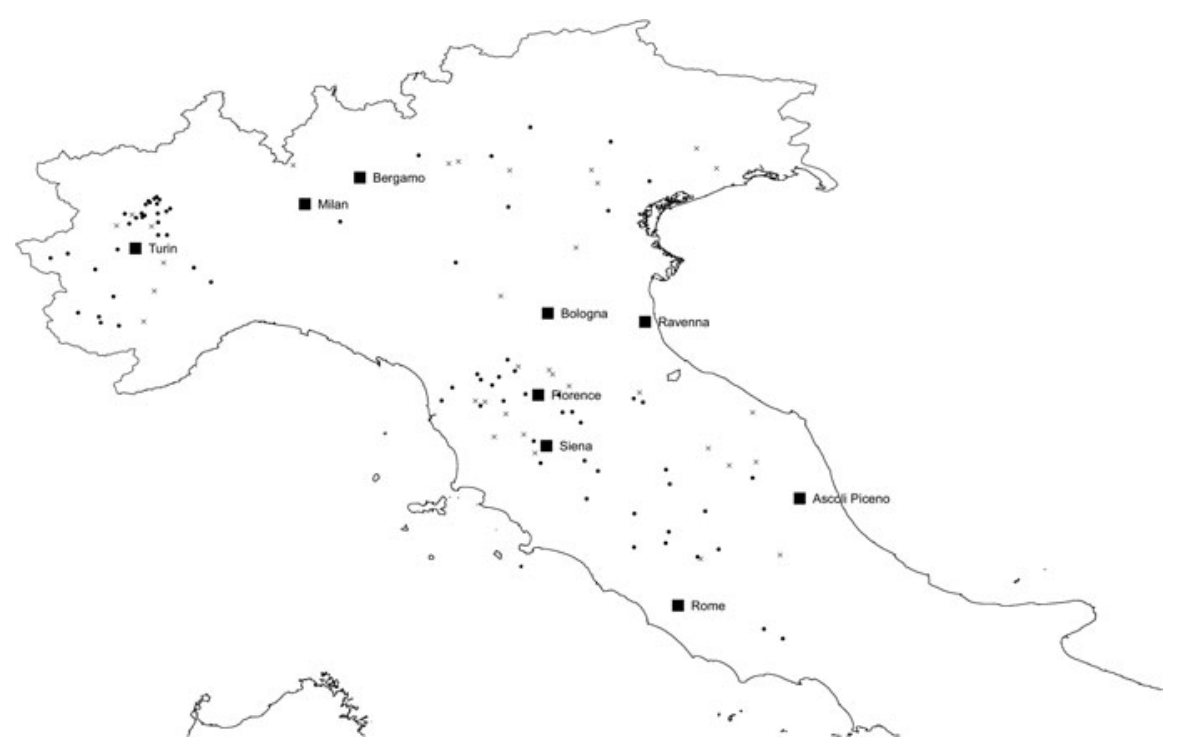

Figure 7. Viarii and camparii in central-northern Italy, c. 1200-1500. Black squares and dots represent sites in which at least one of these outfits operated. Sites that were studied but where no evidence of their activity survives are marked with a grey $\mathrm{x}$.

Source: G. Geltner, Roads to Health: Infrastructure and Urban Wellbeing in Later Medieval Italy (Philadelphia, 2019).

by Galenic preventative health principles to differing degrees. Figure 7 depicts 84 sites where roads officials or viarii operated between 1250 and 1500, and who often had as their rural counterparts a group of camparii or field masters looking after hinterland infrastructure to secure urban flows of energy and waste. These groups, to recall, worked alongside numerous other municipal officials as well as guild members, charitable organizations, university advisors, the church and local physicians to fight disease and promote health among all urban dwellers.

Nor was this state of affairs unique to Italy. Viarii and other infrastructure specialists, not to mention guild, medical, military and religious officials who occupied themselves with communal health, are well attested for numerous cities since their foundation and proliferation in the British Isles, Iberia, Germany, the Low Countries, Scandinavia, the Balkans, Byzantium and elsewhere. ${ }^{36}$ That is not to argue for a uniform healthscape or healthscaping practices across western Europe, let alone the pre-modern world, even in regions that shared a learned medical tradition. Across the vast Islamicate world, for instance, the work of a religious urban official called the muhtasib, or market inspector, involved the regular monitoring of public hygiene since at least the ninth century, working within a decidedly Galenic paradigm but defining himself as a moral custodian of the city. ${ }^{37}$

\footnotetext{
${ }^{36}$ An updated bibliography on pre-modern public health in different world regions is available at: https:// premodernhealthscaping.hcommons.org/documents/.

${ }^{37} \mathrm{P}$. Chalmeta Gendrón (ed.), “El 'Kitāb fỉ Ādāb al-Hisba" (Libro del buen gobierno del zoco) de Al-Saqatî', Al-Andalus, 32 (1967), 125-62 and 359-97; 33 (1968), 143-95 and 367-434; 'Abd al Rahman b. Nasr al-Shayzarī, The Book of the Islamic Market Inspector [Nihāyat al-Rutba fĩ Talab al Hisba (The
} 
Given the overlap in medical paradigms between vast swathes of the pre-modern world, the geospatial analysis of data from Bologna offers some parameters and indicators for, in the first instance, preventative health measures in a humoralmedical context and a fortiori awareness thereof. Furthermore, it tests a methodology for tracing change over time and in response to diverse events and processes, including war, famine, epidemic disease, political upheaval, economic downturns and administrative overhauls. The rare abundance of Bolognese documents thus offers a unique opportunity, yet at the same time emphatically rejects the notion that these types of data are the only valid indicators for the existence and quality of group prophylactics. ${ }^{38}$ If, however, they do open up vistas for scholars working on different societies and medical and environmental paradigms, we will have taken a small step towards a flexible and inclusive methodology that would foster more transregional and comparative dialogue.

\section{Appendix}

\begin{tabular}{|c|c|c|c|c|c|c|}
\hline \multirow[b]{2}{*}{ Offence type } & \multicolumn{2}{|c|}{$1287-1323 \bullet$} & \multicolumn{2}{|c|}{$1330-47^{\bullet}$} & \multicolumn{2}{|c|}{$1355-83^{\bullet}$} \\
\hline & N (mappable) & $\%$ of total & N (mappable) & $\%$ of total & N (mappable) & $\%$ of total \\
\hline 1. Animals & $307(160)$ & 15.73 & $6(4)$ & 1.62 & $1(1)$ & 0.08 \\
\hline 2. Blockage ${ }^{1}$ & 137 (133) & 7.02 & $42(36)$ & 11.35 & $64(50)$ & 5.30 \\
\hline 3. Building violation & 0 & 0.00 & $2(2)$ & 0.54 & 0 & 0.00 \\
\hline 4. Commerce $^{2}$ & $457(291)$ & 23.41 & 216 (179) & 58.38 & $784(298)$ & 64.95 \\
\hline 5. Damage & 0 & 0.00 & 0 & 0.00 & $8(0)$ & 0.66 \\
\hline 6. Filth ${ }^{1}$ & $304(274)$ & 15.57 & $45(37)$ & 12.16 & $136(98)$ & 11.27 \\
\hline 7. Gambling & 0 & 0.00 & $5(5)$ & 1.35 & $18(0)$ & 1.49 \\
\hline 8. Neglect $^{1}$ & $724(644)$ & 37.09 & $32(12)$ & 8.65 & $4(2)$ & 0.33 \\
\hline 9. Prostitution & 0 & 0.00 & 0 & 0.00 & $8(8)$ & 0.66 \\
\hline 10. Safety & $3(0)$ & 0.15 & $15(2)$ & 4.05 & $179(0)$ & 14.83 \\
\hline 11. Unknown & $20(20)$ & 1.02 & $7(3)$ & 1.89 & $5(3)$ & 0.41 \\
\hline Totals & $1,952(1,522)$ & 100 & $370(280)$ & 100 & $1,207(460)$ & 100 \\
\hline
\end{tabular}

${ }^{\star}$ The three periods total 3,529 records. There are also 11 undated records which fall between 1286 and 1370. - Not all years are represented for each period, as explained above.

${ }^{1}$ The categories of blockage, filth and neglect were combined into one for GIS analysis.

${ }^{2}$ Commerce was analysed as a stand-alone category in GIS.

Source: ASB Fango.

Utmost Authority in the Pursuit of Hisba)], trans. R.P. Buckley (Oxford, 1999); A. Ghabin, Hisba, Arts and Craft in Islam (Wiesbaden, 2009); T.F. Glick, 'Muhtasib and mustasaf: a case study of institutional diffusion', Viator, 2 (1971), 59-81; T.F. Glick, 'New perspectives on the Hisba and its Hispanic derivatives', Al-Qantara, 13 (1992), 475-89.

${ }^{38}$ See G. Geltner and J. Coomans, 'Public health beyond the simplex of the pre: a multiscalar methodology', forthcoming.

Cite this article: Zaneri T, Geltner G (2022). The dynamics of healthscaping: mapping communal hygiene in Bologna, 1287-1383. Urban History 49, 2-27. https://doi.org/10.1017/S0963926820000541 